International Journal of Linguistics, Literature and Translation

ISSN: 2617-0299 (Online); ISSN: 2708-0099 (Print)

DOI: 10.32996/ijltt

Journal Homepage: www.al-kindipublisher.com/index.php/ijltt

\title{
The Sayings about the Manchu Lady in Maugham's The Painted Veil
}

\author{
Feng Mei 8 (D) \\ School of Foreign Languages, China West Normal University, Nanchong, China \\ $\triangle$ Corresponding Author: Feng Mei, E-mail: 1032154627@qq.com
}

\begin{tabular}{|c|c|}
\hline ARTICLE INFORMATION & ABSTRACT \\
\hline Received: July 08, 2021 & In Maugham's novel, The Painted Veil, many Chinese characters are depicted in it. This \\
\hline Accepted: August 04, 2021 & paper will focus on the Chinese declined aristocrat, the Manchu Lady, one of the \\
\hline DOI: 10.32996/ijllt.2021.4.8.5 & $\begin{array}{l}\text { Lady can be divided into two parts: the things we heard and saw about her and our } \\
\text { stress will lay on the former one, for she is the only character aroused the westerner's }\end{array}$ \\
\hline
\end{tabular}

Maugham; The Painted Veil; Image

William Somerset Maugham, a highly prolific and renowned writer and is also a very popular writer in China. It has nearly been a century since his book was first introduced to China in 1920s. Today, his works are still warmly welcomed by Chinese readers of all ages, and some are compiled into textbooks for the students. His representative works including: of Human Bondage, The Moon and Sixpence, The Razor's Edge, and The Skeleton in the Cupboard. Also, his countless short stories and plays can not be neglected. He devoted his life and passion to writing and travel. On the one hand, he wrote many famous novels, essays, and plays. On the other hand, he printed his footsteps in many places. Maugham has travelled to plentiful places all over the world. What he has seen during the journey then became the writing materials of his later works. Among all his works, a large number of them are welcomed by readers from every corner of the world. He was titled "one of the most popular English writers in the $20^{\text {th }}$ century" (Liu, 1988). As Maugham travelled so much, and he was such an excellent observer, the things he saw, the people he met, the stories he heard then become part of his writings. In addition, his works also enjoy a high reputation for the exotic descriptions of the other countries and people. Moreover, the stories in his writings are always charming and bewitching, and they touch hearts much by means of their plot and those vivid characters.

There are many characters with exoticism in Maugham's writings, which provide a good chance for those who never have the chance to go aboard to appreciate the things and people that they are unfamiliar with. In all his exotic depictions, the east is a charming part and can never be neglected. For instance, in his famous novels: of Human Bondage, On a Chinese Screen and The Painted Veil, we could catch an eye on those Chinese characters from all walks of life: Chinese servants, Chinese curio dealers, the bearers, soldiers, the beggars dead or alive, the cook, the collies, the peasants, the passers-by, the Manchu lady, the little Chinese girls and newborn babies and the woman with bound feet. As we have listed before, in Maugham's novel, The Painted Veil, Chinese people in all social statuses were portrayed in it, so in this paper, we will focus on one of those characters, the declined Chinese aristocrat, a young Manchu Lady. Comparing with the other Chinese characters delineated in this novel, the Manchu Lady, or the Manchu Princess, catch the writer's eyes more, therefore. Therefore, the author has given more words to the Manchu Lady, not like the other Chinese characters just be given a few words. Moreover, the other characters are all full of negative descriptions and do not influence the protagonists and the development of the plot, but the Manchu Lady is different. She is important to the development of the story. So in this paper, we will try to analyze the cultural meaning and connotation of the Manchu lady thoroughly from the perspective of Imagology and combine it with the plot of the novel.

\section{K C AL-KINDI CENTER \\ R D FOR RESEARCH AND DEVELOPMENT}

Your gateway to world-class research

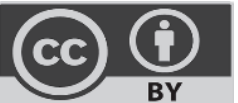

Published by Al-Kindi Center for Research and Development, London, United Kingdom. Copyright (c) the author(s). This open access article is distributed under a Creative Commons Attribution (CC-BY) 4.0 license 
This growing field of study, known as Imagology or Image Studies, an important branch of Comparative Literature, generally defines itself as studying national and ethnic characteristics or stereotypes in cultural and textual production. Put more simply. It is the study of how one nation or group imagines another in discourse. The Manchu Lady depicted in the novel is a result of the trans-cultural communication of the east and the west and a combination of objective description of the east and the writer's personal imagination. As we can see from what Pierre Brunel once said that, a foreigner's impression of a country could never be the same as what the local citizen want him to be. In other words, emotional factors overwhelm the objective one(Brunel 2001). So the foreigners depicted in the writer's work can not be the same as what the local people truly are, and furthermore, the writer's opinion will be influenced by the historical and social background that he lived in, so the characters depicted in the works are the combinations of both the author's imagination and the social reflection, that is to say, when we pay our attention to the images what really matters is not if the images are the same as the original one or not, but the psychological framework of the image builder. We need to know the social and historical background of the writer when it comes to the unveiling of the connotation and cultural meaning of the declined aristocrat depicted in the Maugham's The Painted Veil. This is also coincident with what contemporary Imagology focuses on the "image" matter and the "image builder" matters a lot. As the famous Chinese Comparative Literature scholar Meng Hua says that if you want to know the critical consciousness of the image builder, the first thing you need to do is to get a clear understanding of the society the writer lived in. The writer's attitude towards exotic others is not in a vacuum circumstance. The social surroundings would influence him. Only when we can draw a clear picture of the social image of that time can we get a clue of the writer's attitude towards the exotic other, whether the author favours the imaginary social of that time or not. But in the $19^{\text {th }}$ century, the westerners had a very bad impression of the east, the words used to describe the east were "savage"," inhuman" "beastly" $(\mathrm{Ge}, 2002)$, so perhaps Maugham's attitude toward the east could not be very optimistic.

Maugham was born in 1874 and ceased to think in 1965. During the long-lasting period of his life, the world was in dramatic change. At that time, transnational communications were in an active status than ever. The development of modern transportation deeply changed people's way of knowing other countries, and offered a great chance for those travellers, especially for those who had a passion for the distant and exotic countries, they embarked on new adventures on their own and set their foot to the land they have never been to before. In the year of 1919, with his secretary, Maugham went to China for the first time in his fifties, and he stayed in China for nearly four months. In this remote journey, he had been to many places in China, for instance, Beijing, Shanghai, Hankou and Sichuan, and some even more distant countries. In 1920, when he was in Shanghai, he wrote a letter to his friend and bragged that he had travelled for four hundred miles on foot. The people he met, the anecdotes he heard, and the scenery he saw on the journey became part of his writing materials. One of his books, On a Chinese Screen was the fruit of this journey to China. In 1925, his novel The Painted Veil was published. The story of this novel took place in Hong Kong, China. After its publication, the novel was also adapted into film three times and the latest one was produced in 2006, what's worth mention was that the photo shoot of the film was in a village of Guangxi, China.

It was said that, the lines of Dante suggested the story of the novel:

Deb, quando tu sarai tomato al mondo,

E riposato della lunga via,

Seguito il terzo spirito al secondo:

Ricoiditi di me; che son la Pia:

Siena mi fè; disfecemi Maremma:

Salsi colui, che, innanellata pria

Disposando m'avea con la sua gemma.

The novel tells about a domed tragic love story between a beautiful young woman and her husband, a bacteriologist. At the age of 25, Kitty accepted Walter Vane's proposal without much thinking, only to marry herself before her younger sister's wedding and to get rid of her mother's ceaseless tiresome nagging. Not long after their marriage, she found that their marriage was a mistake. A couple of the novel are totally incompatible, Walter Vane loved Kitty with all his heart and soul, but Kitty did not love him so. A few months later, after her marriage, she was bored with his husband, not only his character but also the social status determined by his husband's occupation. When they moved to Hong Kong, she had a passionate affair with Charles Townsend, the Assistant Colonial Secretary, a forty-one-year-old handsome but giddy-brained man. When Walter finds out their amour, he only offered Kitty a choice: either she follows him to a rural outpost, Meitan-fu, where the cholera is breaking out, and he will be volunteered to help to stop the disease or gets her lover, Charles Townsend, to promise to divorce his wife and marry her. Her lover, Charlie Townsend, turns out to be a serial adulterer and he has no intention of leaving his wife, so Kitty, with nowhere else 
to go and no other choice, followed her husband. But things do not always happen as we expected. Kitty just felt like a fish in water, understood the true meaning of life, and got the courage to live a new life after staying in the midst of a terrible epidemic. But Walter, lost his life on the journey.

In this journey to Meitan-fu, we get the chance to know the Chinese declined aristocrat, the lover of Waddington, the Deputy Commissioner of the Customs. When Waddington stayed in Hankow during the revolution, the good little Waddington saved the lives of the girl who belonged to one of the great families, which was related to the Imperial Family. After that, the girl fell violently in love with him and followed him wherever hen went. Like all the romantic love stories, Waddington was the shining knight, but he did not like handsome, ambitious, and courageous knights. Also, he is a funny little thin man with a bald head and a small bare face.

In the history of Western literature, we can find that there are many depictions of the girl from the east fall in love with a man from the west, and generally, the girl is exotic and beautiful, but the man is always not the same normal or handsome as the heroin in the west writings. We can find many examples from the history of western literature, especially in Maugham's novel. The love between the east and west are doomed without a future and can not be blessed. And when we back to the novel, we can find that in chapter 42 , we get to know a tinge of the Manchu Lady for the first time, but we are the same as Kitty, confused, do not understand what are they talking about.

'Monsieur ne mange rien,'said Sister St. Joseph. 'Monsieur's palate is ruined by Manchu cooking, replied the Mother Superior. The smile left Sister St. Joseph's face, and she assumed an expression of some primness. Waddington, a roguish glance in his eyes, took another cake. Kitty did not understand the incident(Maugham, 1977).'

When the novel mentioned the mysterious lady for the first time, it did not talk frankly but rather ambiguous. Mother Superior prepared some cakes for Waddington and Kitty, but Waddington didn't show much interest in it, so she said that the Manchu food ruined Waddington's plate. For it was the first time that kitty had came to the convent, so she was totally confused why Mother Superior would say that, and that was the same to we readers, why? The first time we knew something about the Manchu Lady was very indirect, in others' talking. We could imagine that hundreds of years ago, underdeveloped transportation put a crimp in transnational communications. People in the west didn't get much chance to visit the remote east on their own. So just like the mysterious east, when it first appeared in the world of the west, was not exactly what it truly was, but in the countless stories and legends told by those westerners who were wholly innocent of the east, and those stories and imagination were the places where their imagination began. That is coincident with our way to get to know the Manchu Lady through others' talk and our own imagination. The only thing we get to know was the Manchu cooking, the things related to that woman. Just like the people in the west get to know the Chinese people was through the screens, china, fans and other goods, the pictures on those items provided an approximate outline of their daily lives.

It was the same as the first time in the novel when the novel talked about the Manchu Lady for the second time. In Sister St. Joseph's words, we get to know more about what happened before. In chapter fifty-one, when Kitty was chattering with Sister St. Joseph and they talked about Waddington, Sister St. Joseph said something secretly about Waddington:

Of course, his morals were not all one could wish; but still, that was his business (with a sigh, a shrug and a shake of the head) and he was a bachelor and a young man.'What is wrong with his morals, ma soeur?' asked Kitty smiling.'Is it possible that you do not know? It is a sin for me to tell you. I have no business to say such things. He lives with a Chinese woman, that is to say, not a Chinese woman, but a Manchu. A princess, it appears, and she loves him to distraction.'(Maugham , 1977)

This is what Sister St. Joseph has said about Waddington. In her opinion, Waddington was a good young man with a warm heart and he was willing to help those in trouble. But all the good characters disappeared when she talked about his love affair. She thought it was immoral for him to keep an intimate relationship with a Chinese woman. Here we can see that, for British people, loving a Chinese woman couldn't be accepted by society at that time. Furthermore, they were totally against it. In the novel, Waddington was an ugly little wan with a bald head, comparing with Kitty's lover Charlie, a handsome and tall man, Waddington was disgusting enough in appearance. But, it was this little man who saved the Chinese woman's family and won her heart. Why could he do that? That was not because he had the strength and power, but just he was a foreigner, an easterner. China was a undeveloped, poor, invaded and turbulent country at that time, but the British were different. It was in its thriving and prosperous time. So a man like Waddington could do something remarkable easily because of his nationality and identity. Once people's stereotype of other countries was rooted in people's hearts, they would treat others with their ingrained pride and prejudice: They would think that only people with the same color and blood as themselves can gain their respect. So it was immoral for Waddington to love the Chinese woman, just as she was just not like them. It was the same as Mr. Song, a Chinese gentleman in Maugham's another novel of Human Bondage. Mr. Song fall in love with a French girl, all the people around them totally disagreed with it, that was not because Mr. Song was a bad gay or something else, and on the contrary, he was a wellbreaded and upright young man, the only thing they could not stand was just his identity, a Chinese. So we can see that, 
hundreds of years ago, tremendous gaps in technological and economic development across countries deeply influenced people's attitude toward other countries. Therefore, Waddington's falling in love with the Manchu Lady was a moral taint.

The third time we heard more about the Manchu Lady by the protagonist of the rumor, Waddington. He told us what happened exactly when Kitty and Waddington talked a walk, talked much, and then about the Manchu Lady. The nun in the convent told Kitty that Waddington lived with a Manchu Lady. Moreover, the Manchu Lady was a princess. Kitty asked him why he did not tell her that he lived with a Manchu princess. And then Waddington told Kitty the truth, the Manchu Lady was not a princess but belonged to one of the great families of the Manchus ruined by the revolution. He did not mention specifically how he rescued life her, but mentioned that the Manchu Lady fell helplessly in love with him:

'She's abandoned everything for my sake, home, family, security and self- respect. It's a good many year now since she threw everything to the winds to be with me. I've sent her away two or three times, but she's always come back; I've run away from her myself, but she's always followed me. And now I have given it up as a bad job; I think I have got to put up with her for the rest of my life.'(Maugham ,1977) These words show us that how deeply the girl loved him. As we have seen before, Waddington was an ugly little man. In Kitty's mind, Waddington was a little bald-headed man with a monkey face. How could such a man became a hero. Something worth mention is that he tried to send the girl away many times but failed in the end, so in the beginning, he did not want to accept the girl. The girl is insistent on living with him, and he had no choice but to agree on it. And then he told Kitty that:'I haven't the smallest doubt that if I really left her, she would commit suicide. Not with any ill-feeling towards me, but quite naturally, because she was unwilling to live without me. It is a curious feeling it gives one to know that. It cannot help meaning something to you.'(Maugham, 1977). Here we can see that how deeply the Manchu Lady loved him and how important Waddington was in her life. If he left her, she would commit suicide just because she could not live without him. She was totally different from Kitty, one of our protagonists, who followed her husband to Meitan-fu after being discovered her affair with Charles. The condition here was dramatically awful, the plague was rampant, and people here dead like piles of flies may lose their lives nay minute. To our astonishment, Kitty did not die here, and on the contrary, she did well here and found the true meaning of life. The beautiful young wife, who once was a silly, frivolous and empty-headed girl, finished the self-salvation by her strong will in the journey of rebirth and trail. But for the Manchu Lady, things were totally different. She could not achieve salvation on her own. She needed a man to help her, and perhaps an ugly little man, just because she was a Chinese woman, weak-willed and submissive. She could no longer survive once she was not in the places where she originally belonged, so she couldn't go to the other country with Waddington. What's more, they have lived together for many years, but they didn't have any kids. Kids mean hope and future, but they didn't have, so the relation of the two was doomed without a future.

The Manchu Lady was not just a mysterious girl from the east. She incarnated the remote and exotic east. People in the west were longing to see her, but they just came here to satisfy their own curiosity. They just want to appreciate her at a distance but no intimity. At that time, the west held the east, especially the Chinese, in contempt. That is to say, they don't bless the love between the east and west in order to keep the purity of the east. So just from this part, we can see that Maugham's attitude towards this woman is complicated and negative. He hoped to know more about the Manchu Lady, but it is hard for him to get rid of the ingrained prejudice from the society he belongs.

\section{References}

[1] Ge, G. L. (2002). Distant Voices Beyond London--English Writers and Chinese Culture. Ning Xia: Ningxia people's Publishing House.

[2] Maugham, W. S. (1987). The Painted Veil. New York: Penguin.

[3] Meng H. (2001). Imageologie en littérature comparée. Beijing: Peking University Press.

[4] Said, Edward(1979). Orientalism. New York: Vintage Books.

[5] Liu, X. Z. (1988). Caise de miansha. Beijing: Beijing literature and Art Publishing House, October 